\title{
Do the changes in temperature and light affect the functional response of the benthic mud snail Heleobia australis (Mollusca: Gastropoda)?
}

\author{
THAISA R.F. MAGALHÃES ${ }^{1}$, RAQUEL A.F. NEVES ${ }^{2}$, JEAN L. VALENTIN ${ }^{1}$ and GISELA M. FIGUEIREDO ${ }^{2}$ \\ ${ }^{1}$ Laboratório de Zooplâncton Marinho, Departamento de Biologia Marinha, Instituto de Biologia, Universidade Federal do Rio \\ de Janeiro, Av. Carlos Chagas Filho, 373 - CCS, sala A1-079, Cidade Universitária, 21941-902 Rio de Janeiro, RJ, Brasil \\ ${ }^{2}$ Laboratório de Ecologia Trófica, Departamento de Biologia Marinha, Instituto de Biologia, Universidade Federal do Rio de \\ Janeiro, Av. Professor Rodolpho Rocco, 211 - CCS, sala A1-079, Cidade Universitária, 21949-900 Rio de Janeiro, RJ, Brasil
}

Manuscript received on March 7, 2013; accepted for publication on September 9, 2013

\begin{abstract}
The aim of this study was to determine the influence of temperature increase combined to conditions of light incidence on functional response of Heleobia australis. Experiments were conducted using nine to ten food concentrations for each treatment: $20^{\circ} \mathrm{C}$ without light; $30^{\circ} \mathrm{C}$ without light and, $30^{\circ} \mathrm{C}$ under low light intensity. For each experiment, the functional response type III (sigmoidal) was fitted and equation parameters were determined. Results suggest that, if the sediment temperature increases, $H$. australis will not have its ingestion rates affected negatively, whilst its feeding behavior seems to be negatively affected by light. Ingestion rates estimated for organic content in the Guanabara Bay were: $0.34 \mu \mathrm{gC}$ ind $^{-1} \mathrm{~h}^{-1}$ at $20^{\circ} \mathrm{C}$ without light, $1.44 \mu \mathrm{gC}$ ind ${ }^{-1} \mathrm{~h}^{-1}$ at $30^{\circ} \mathrm{C}$ without light and $0.64 \mu \mathrm{gC}$ ind $^{-1} \mathrm{~h}^{-1}$ at $30^{\circ} \mathrm{C}$ under light incidence. Higher ingestion rates were estimated at the high temperature, even under light incidence, and temperature seems to have outweighed the light effect. In contrast, if higher carbon content is considered, despite high temperature, the experiment conducted with light incidence showed lower ingestion rates than those from the experiment at $20^{\circ} \mathrm{C}$ without light. This study provides the first quantification of $H$. australis ingestion rates and the effects that changes in temperature and light have on its feeding behavior.
\end{abstract}

Key words: Hydrobiid, ingestion rates, estuarine system, gastropod.

\section{INTRODUCTION}

Heleobia australis is distributed from Rio de Janeiro, Brazil, to western San Antonio, Argentina and occurs in estuarine systems and coastal lagoons, generally, associated to shallow areas $(0.4-3.5 \mathrm{~m})$ with anoxic-mud sediment (Gonçalves Jr et al. 1998, Albertoni et al. 2003, De Francesco and Isla 2003, 2004, Figueiredo-Barros et al. 2006, Alda et al. 2010). In the Guanabara Bay, Brazil, it is the

Correspondence to: Raquel A.F. Neves

E-mail: neves.raf@hotmail.com dominant benthic species in shallow waters (Neves et al. 2013). Heleobia australis compose the diet of some commercially important estuarine fishes and crustaceans such as: whitemouth croaker Micropogonias furnieri (Figueiredo and Vieira 1998), shrimps Macrobrachium acanthurus, Farfantepenaeus brasiliensis, F. paulensis (Albertoni et al. 2003, Jorgensen et al. 2009) and the swimming crab Callinectes sapidus (Kapusta and Bemvenuti 1998, Oliveira et al. 2006). Heleobia australis feeds on the surface sediment (Bemvenuti et al. 1992), 
microphytobenthos (Alvarez et al. 2013), and likely its food sources are similar to other hydrobioids that feeds on organic matter, diatoms, dinoflagellates, ciliates and bacteria (Kofoed 1975, Bianchi and Levinton 1984, Blanchard et al. 2000, Sokolowski et al. 2005, Pascal et al. 2009). Thus, H. australis plays a role as a link between the benthic microbial food web and the upper consumers. Estimates of $H$. australis ingestion rates may contribute to the understanding of the estuarine food web.

Ingestion rates may be affected, within other factors, by changes on the estuarine sediment in terms of organic matter content, temperature and light incidence, which are consequence of natural and anthropogenic impacts, such as eutrophication, global warming and siltation as explained below.

Coastal areas and estuaries are constantly receiving inputs of domestic and/ or industrial waste (Smith et al. 1999), which increases the availability of organic matter, a potential food source for the deposit feeders (Nixon 1995, Espinosa et al. 2007, Rao and Charette 2012). The increase in ingestion rates in response to increasing food density was defined as a 'functional response' by Holling (1959), who recognized three major types of responses described as a functional response: i) type I - the consumption rate rises linearly with prey density, ii) type II - consumption rate rises with prey density, but gradually decelerates until a plateau is reached (hyperbola) and iii) type III - similar to a type 2, but at low prey densities the type 3 response has an accelerating phase where an increase in density leads to a more than linear increase in consumption (sigmoidal) (Begon et al. 2006).

In addition, global warming has been strongly related to the increase of water temperature (Rabalais et al. 2009), that affects the organism's metabolism and, therefore, influence species feeding rates and functional responses (Hylleberg 1975, Abdel-Hamid et al. 1992, Bougrier et al. 1995, Gitonga et al. 2002, Pascal et al. 2008, Rico-Villa et al. 2009). Higher temperature tend to increase ingestion rates up to a maximum, above which any temperature increase would inhibit the ingestion rates, as demonstrated for Hydrobia ulvae (Hylleberg 1975, Pascal et al. 2008), H. neglecta and H. ventrosa (Hylleberg 1975).

Finally, the marginal areas of estuaries are becoming worldwide shallower by a process of siltation; i.e. Bahia Blanca estuary - Argentine (Cuadrado et al. 2006), Guanabara Bay - Brazil (Godoy et al. 2012), Jiaozhou Bay - China (Liu et al. 2012), Keu River Estuary- Korea (Kim et al. 2006), Mandovi and Zuari estuaries - India (Rao et al. 2011), Ord River estuary - Australia (Wolanski et al. 2001). This process is either originated by natural causes over large temporal scale (circulation processes) or by rapid changes in response to environmental and man-made modifications to the hydrologic regimes (Wolanski et al. 2001). Siltation is characterized by an increase in sedimentation rate (Bach et al. 1998), that may reduce the water column making the sediment subject to higher influence of temperature and light incidence or increase in suspended sediment particles thereby increasing turbidity. Light intensity potentially affects species behavior (Russel 1926) and, therefore, it may affect the feeding of benthic species. In contrast, the raise of sea level may increase the water column depth and decrease the incidence of light on the sediment (Kennedy et al. 2002). Thus, habitat changes may affect the organisms that live or feed on the sediment and increase the relevance of experimental studies as a first approach to understanding how organisms respond to environmental changes.

The aim of the current study was to determine the effect of temperature and light increase on the functional responses of $H$. australis, thus three experimental conditions were described: i) the averages of temperature and light incidence from where H. australis occurs in the Guanabara Bay $\left(20^{\circ} \mathrm{C}\right.$ without light), ii) higher temperature without light and iii) higher temperature under low light incidence. 
The latter two conditions attempt to represent possible scenarios that $H$. australis may be susceptible to changes on the coastal estuarine habitats.

\section{MATERIALS AND METHODS}

STUDY AREA

The Guanabara Bay is one of the largest bays in Brazil, with drainage that covers $4.080 \mathrm{~km}^{2}$ with 45 rivers and streams (JICA 1994). The bay is a semienclosed water body surrounded by urban areas and is one of the most degraded estuarine systems along the Brazilian coast (Valentin et al. 1999) exposed to constant human impacts, i.e. river canalisation and landfills, inputs of untreated domestic sewage and industrial residues, ship-source oil pollution, and urban wastes. The Bay has a semi-diurnal tidal regime with tide amplitude ranging from 0 to $1.4 \mathrm{~m}$ (Amador 1997), and the sedimentation rates are approximately $1 \mathrm{~cm}^{\text {year }}{ }^{-1}$, representing an increment of five-fold compared to the sedimentation rates described in the 1950s (Godoy et al. 2012). Temperature and light intensity on the sediment of shallow areas of the Guanabara Bay ranges, respectively, from 16 to $26^{\circ} \mathrm{C}$ and from dark to $40 \mu \mathrm{mol} \mathrm{m} \mathrm{m}^{-2} \mathrm{~s}^{-1}$ (personal observation).

\section{SAMPLING AND EXPERIMENT DESIGN}

Specimens of $H$. australis were collected in May and September 2010, using a Van Veen grab $\left(0.05 \mathrm{~m}^{2}\right)$ at a fixed sampling station (3-5 $\mathrm{m}$ deep) located in one of the most organic polluted areas of the Guanabara Bay. Sediment samples were sieved through $0.05 \mathrm{~mm}$ mesh, and individuals were transported to the laboratory in local water. Temperature and salinity of bottom water were measured using a thermosalinometer. Five sediment samples were collected and the upper layer $(\sim 10 \mathrm{~cm})$ of the sediment was dried for $48 \mathrm{~h}$ at $60^{\circ} \mathrm{C}$ (APHA 1998). Sediment organic matter was determined from the weight loss after ignition at $500^{\circ} \mathrm{C}$ during $4 \mathrm{~h}$, and carbon content was estimated according to Schumacher (2002).
The individuals of $H$. australis ( $\sim 2 \mathrm{~mm} ; \sim 0.30$ mg dry weight) were transferred to Petri dishes ( $9 \mathrm{~cm}$ in diameter) with $30 \mathrm{ml}$ of filtered (GF/F) water from the Guanabara Bay. The density in each Petri dish was 17 individuals, a number described as appropriate to avoid density-dependent effects for a larger species $(3-4 \mathrm{~mm})$, e.g. Hydrobia ulvae (Blanchard et al. 2000). Functional response estimates were conducted measuring ingestion rates at nine to ten different food concentrations, for each treatment: 1) temperature of $20^{\circ} \mathrm{C}$ without light; 2) temperature of $30^{\circ} \mathrm{C}$ without light; and 3) temperature of $30^{\circ} \mathrm{C}$ under light incidence of $16 \mu \mathrm{mol} \mathrm{m} \mathrm{m}^{-2} \mathrm{~s}^{-1}$. Individuals were acclimated to each experiment condition and food concentration for $24 \mathrm{~h}$, and kept in filtered water during $2 \mathrm{~h}$ for egestion, as proposed for H. ulvae (Calow 1975). Simultaneously, controls were done for each food concentration in the same conditions as those for the treatments, but without the snails. Treatments and controls were incubated for $2 \mathrm{~h}$ and were conducted in triplicate for each food concentration.

Water and food were filtered through GF/F membranes, dried in an oven at $60^{\circ} \mathrm{C}$ for $48 \mathrm{~h}$, and then weighed on analytical balance to determine food concentration in terms of carbon dry weight. Artificial food for invertebrates (fine powder, SeraMicron $^{\circledR}$ ), containing $50.2 \%$ crude protein, was used in the experiments. The carbon content of the food was determined assuming a conversion factor of 0.86 Carbon: protein (Simon and Azam 1989).

Food concentrations at the beginning and end of experiment, both in treatments and controls, were compared using a t-test. At each concentration of food, the variation in food quantities over the experiment duration $(2 \mathrm{~h})$ were compared between treatments and controls, also using a t-test. In the controls there were no differences between food concentrations at the beginning and end of experiments $(p>0.05)$. Thus, the controls were not used to estimate ingestion rates. Ingestion rates $\left(\mu \mathrm{gC}\right.$ ind $\left.^{-1} \mathrm{~h}^{-1}\right)$ were estimated 
by the variation of food concentration at the beginning and end of experiment and divided by the number of individuals in the Petri dish $(n=17)$ and the experiment duration $(2 \mathrm{~h})$. The ingestion rates were plotted against food concentration (Functional Response) and a non-linear regression was determined using the software Sigma Plot 10.0. Using a t-test, the curve parameters were compared between experiments with different lighting condition and same temperature and between experiments with different temperatures and absence of light.

\section{RESULTS}

During the samplings the water temperature in the field ranged between 20 and $23^{\circ} \mathrm{C}$ at the bottom and surface, respectively. The mean organic-matter content in the sediment was $203 \mu \mathrm{g} \mathrm{ml}^{-1}$ sediment ( \pm 0.03 ), corresponding to $107 \mu \mathrm{gC} \mathrm{ml}^{-1}$ sediment.

The decrease of food during the experiment was significantly higher $(\mathrm{p}<0.01)$ in the replicates with $H$. australis than in the control, for all food concentrations and treatments, showing that there was ingestion of the artificial food offered to snails. Functional responses (Fig. 1) showed the best fit to the non-linear regression Type III (Hill equation, $\left.\mathrm{I}=\left(\mathrm{I}_{\max } \cdot \mathrm{x}^{\mathrm{b}}\right) /\left(\mathrm{k}^{\mathrm{b}}+\mathrm{x}^{\mathrm{b}}\right)\right)$, where $\mathrm{I}$ is Ingestion Rate, $I_{\max }$ is the Maximum Ingestion Rate, $\mathrm{k}$ is the Coefficient of Half-Saturation, $\mathrm{b}$ is the parameter of Hill Equation and $\mathrm{x}$ is the Food Concentration. The parameters of functional response equation are shown in Table I.

Experiments performed in the dark at 20 and $30^{\circ} \mathrm{C}$ showed a trend to reach the asymptote in food concentration $\sim 170 \mu \mathrm{gC} \mathrm{ml}{ }^{-1}$ (Fig. 1). Comparisons of equation parameters did not show significant differences, except for parameter $\mathrm{k}$, which was significantly higher at $20^{\circ} \mathrm{C}(\mathrm{t}$-test, $\mathrm{p}<0.05)$. Thus, $H$. australis reached half-saturation in lower food concentrations at $30^{\circ} \mathrm{C}$.

Comparisons between the experiments conducted at $30^{\circ} \mathrm{C}$, with and without light incidence,
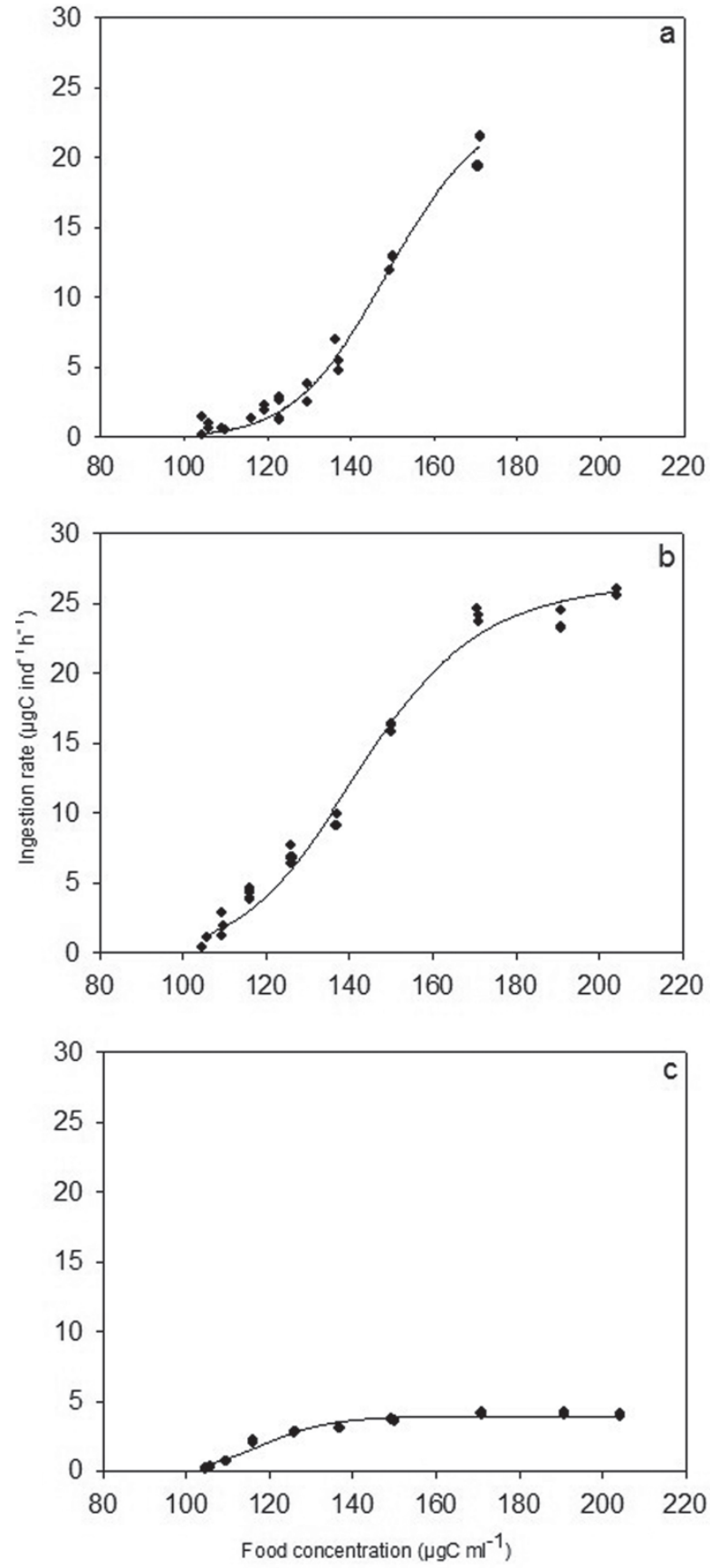

Fig. 1 - Heleobia australis functional responses estimated for (a) $20^{\circ} \mathrm{C}$ in darkness, (b) $30^{\circ} \mathrm{C}$ in darkness, and (c) $30^{\circ} \mathrm{C}$ in light intensity of $16 \mu \mathrm{mol} \mathrm{m} \mathrm{m}^{-2} \mathrm{~s}^{-1}$.

showed differences between all parameters (t-test, $\mathrm{p}<0.05)$. The experiment carried out with light showed a significantly higher $b$ than the experiments conducted in the dark $(p<0.05)$, and the $\mathrm{I}_{\max }$ was $\sim 7$-fold lower under the light incidence. 
TABLE I

Parameters, coefficient of determination and $p$ values for the statistically significant functional responses determined for the experiments conducted with Heleobia australis. Different letters indicate that parameters were significantly different (t-test, $p<0.05$ ).

\begin{tabular}{cccccc}
\hline \multirow{2}{*}{ Experiments } & \multicolumn{5}{c}{ Parameters } \\
\cline { 2 - 6 } & $\begin{array}{c}\mathrm{I}_{\max } \\
\left(\mu \mathrm{gC} \cdot \mathrm{Ind}^{-1} \cdot \mathrm{h}^{-1}\right)\end{array}$ & $\mathrm{b}$ & $\begin{array}{c}\mathrm{K} \\
\left(\mu \mathrm{gC} \cdot \mathrm{ml}^{-1}\right)\end{array}$ & $\mathrm{R}^{2}$ & $<0.0001$ \\
\hline $20^{\circ} \mathrm{C}$ in the dark & $24.9^{\mathrm{a}}$ & $12.7^{\mathrm{a}}$ & $150^{\mathrm{a}}$ & 0.98 & $<0.0001$ \\
$30^{\circ} \mathrm{C}$ in the dark & $26.6^{\mathrm{a}}$ & $9.9^{\mathrm{a}}$ & $143^{\mathrm{b}}$ & 0.98 & $<0.0001$ \\
$30^{\circ} \mathrm{C}$ in the light & $3.96^{\mathrm{c}}$ & $15.2^{\mathrm{c}}$ & $119^{\mathrm{c}}$ & 0.96 & $\mathrm{p}$ \\
\hline
\end{tabular}

$\mathrm{I}_{\max }$, maximum ingestion; $\mathrm{K}$, half-saturation coefficient; $\mathrm{b}$, Hill coefficient; $\mathrm{R}^{2}$, correlation coefficient.

\section{DISCUSSION}

Few studies describe ingestion rates and functional responses of benthic deposit feeders. Functional responses of $H$. australis showed a progressive increase with food concentration tending to reach an asymptote, this pattern is similar to that of some invertebrates as the bivalve Abra ovata (Grémare et al. 2004), the polychaete Abarenicola pacifica (Hymel and Plante 2000, Linton and Taghon 2000) and also the hemichordate Saccoglossus kowalevskii (Karrh and Miller 1994). Moreover, the ingestion rates of $H$. australis in low food concentrations were in the range of those found for other gastropods; Hydrobia truncate, H. ulvae and hydrobiid feeding on diatoms and bacteria (Haubois et al. 2005, Pascal et al. 2008, 2013). Based on previous studies, in which the functional response did not reach the asymptote, we provided larger amount of food attempting to better describe the functional responses. As a result, $H$. australis presented high ingestion rates at high food concentrations that have not been examined before. Despite the use of artificial food, the results suggest that the snails did not avoid this type of food, but on the contrary they ingested large amounts of it. In the current study, the food was not mixed to the sediment and considering that the mixture of food and sediment may increase the time of food manipulation, our estimates of ingestion rates may have been overestimated. Although the extrapolations from our results to natural environment require caution (see below), our study was representative to describe the effects of temperature and light incidence on the feeding behavior of $H$. australis.

Functional responses for all experiments had the best fit to Type III curve. The difference between Type II and III responses is the concavity (slowdown) in the early part of the curve, which is determined by several factors that influence the time predators spend searching and handling food (Holling 1965, 1966), i.e. predator efficiency. Generally, this efficiency tends to increase with the number of encounters between predator and prey that is described by parameter " $b$ " in the equation of functional response Type III. Thus, predators with higher efficiency require lower encounter rates to ingest their prey and, therefore, the values of parameter " $b$ " in their functional response are lower. In fact, when $b=1$, the equation of functional responses Type II and III are equal, and the difference between the responses is interpreted as a slow learning behavior of predator at the initial portion of the response type III (Real 1977).

Experiments performed with no light incidence at 20 and $30^{\circ} \mathrm{C}$ did not show stabilization of functional responses, only a trend to reach the asymptote. The half-saturation coefficient (k) was significantly higher at $30^{\circ} \mathrm{C}$, indicating higher ingestion rates in lower food concentrations than at $20^{\circ} \mathrm{C}$. It is possible that individuals were more active and potentially more efficient in their food search at higher temperatures. Although comparisons 
between temperate and tropical organisms should be carefully conducted, it was also demonstrated that the polychaete Abarenicola pacifica (Hymel and Plante 2000) and hydrobiids (Pascal et al. 2008) showed higher ingestion rates at $30^{\circ} \mathrm{C}$, when experiments were conducted in a range of temperatures. In the present study, we did not determine the temperature which resulted in the maximum ingestion rate for $H$. australis, but noted that if the sediment temperature increases (i.e. $30^{\circ} \mathrm{C}$ ) H. australis will not have its ingestion rates affected negatively. However, further studies concerning the gastropod metabolism are necessary to assess possible changes in food requirement due to temperature increase.

Comparisons between the experiments conducted with and without light at $30^{\circ} \mathrm{C}$ indicated differences in all curve parameters. When exposed to light, even low incidence, $H$. australis showed significantly lower $\mathrm{k}$ and $\mathrm{I}_{\max }$ and higher " $\mathrm{b}$ ", which means that it was less efficient in finding its food and, in order to reach a given ingestion rate, it will require higher food densities than those snails from the experiments conducted with no light incidence. Moreover, the maximum ingestion rate of $H$. australis was $\sim 7$-fold lower under light incidence. Studies have shown that feeding rates may be positively (Buikema 1973, Orvain and Sauriau 2002, Barnes 2003), negatively (Barnes 1986) or nonaffected by light (Bianchi and Levinton 1984, Pascal et al. 2008). Here, feeding rates of $H$. australis were affected by lower light incidence than the maximum value we recorded for the Guanabara Bay (i.e. $40 \mu \mathrm{mol}$ $\mathrm{m}^{-2} \mathrm{~s}^{-1}$ ). Thus, it is possible that light might already be influencing feeding behavior and, consequently, the growth of this species in the bay.

Applying the organic carbon content measured at the sampling site to the functional responses equation (see parameters in Table I), the following ingestion rates were calculated of: $0.34 \mu \mathrm{gC}$ ind $^{-1} \mathrm{~h}^{-1}$ at $20^{\circ} \mathrm{C}$ without light incidence, $1.44 \mu \mathrm{gC}$ ind $^{-1} \mathrm{~h}^{-1}$ at $30^{\circ} \mathrm{C}$ without light incidence and $0.64 \mu \mathrm{gC}$ ind $^{-1} \mathrm{~h}^{-1}$ at $30^{\circ} \mathrm{C}$ under light incidence. Although the ingestion rates may have been overestimated, as $H$. australis was fed only on pure food and not on food combined to the sediment (see above), this study provided the first quantification of ingestion rates of $H$. australis and it serves as a basis for future estimates of carbon transfer to the upper trophic levels. Moreover, this study enabled us to make predictions of the effects of environmental conditions on the ingestion rates. It is important to note that, in food concentrations at the initial portion of the curve, corresponding to organic carbon content from $\sim 100$ to $128 \mu \mathrm{gC} \mathrm{ml}^{-1}$, which includes the carbon content at the sampling site, the lowest ingestion rates occurred at the experimental condition of $20^{\circ} \mathrm{C}$ with no light incidence, which is the one often found at shallow waters of the Guanabara Bay. At these food concentrations, the ingestion rates of $H$. australis were at the beginning part of the type III curve i.e. before the concavity (slowdown) (Fig. 1). Thus, considering ingestion rates at the specific organic carbon content of the Guanabara Bay sediment, at high temperature $\left(30^{\circ} \mathrm{C}\right) \mathrm{H}$. australis showed higher ingestion rates even when exposed to light incidence, showing that the effect of temperature seems to have outweighed the light effects. In contrast, if higher carbon content is considered, despite the high temperature, the experiment with light incidence showed lower ingestion rates for $H$. australis than that conducted at $20^{\circ} \mathrm{C}$ without light incidence. Temperature does not seem to be the only factor determining feeding behavior. Barnes (2006) pointed out the importance of other factor, i.e. tidal cycle, influencing the feeding behavior of Hydrobia ulvae. Here, it is shown that opposing results can be obtained if ingestion rates are analyzed at one specific food concentration instead of at a range of food concentrations. More studies approaching functional response experiments are necessary as they provide more consistent predictions about the effects of environmental changes on feeding behaviors.

In this study, we evaluated the influence of temperature increase combined to changes in light on the functional response of $H$. australis. There is 
no prediction of how temperature and light covariate in the bottom of shallow areas of the Guanabara Bay and other estuaries, and this topic is beyond the aim of the current study. However, the process of siltation, which decreases the water column depth, was already recorded for the Guanabara Bay (Godoy et al. 2012) and, therefore, two scenarios may be expected: i) light incidence on the sediment decreases due to high water turbidity by suspended sediment particles; or ii) light incidence on the sediment increases as water column depth decreases enough that, despite particles in suspension, the light reaches the sediment. In the specific case of the Guanabara Bay, there is a frequent entrance of coastal waters, including the South Atlantic Central Waters, which reaches shallow areas and increases the water column transparency. Thus, applying our results to the scenario where temperature, light and food content (organic carbon) increase, which is a possible situation to occur in the Guanabara Bay, ingestion rate would decrease in relation to current conditions of this bay. On the other hand, if temperature increases, light might either increase or not, but organic content on the sediment would remain as it is today, then the ingestion rates of $H$. australis would increase. Further studies approaching a wide temperature range and light incidence on feeding and growth of $H$. autralis and other benthic species will be useful to make other predictions about the effects of environmental changes on coastal habitats.

\section{ACKNOWLEDGMENTS}

R.A.F. Neves was financially supported by a fellowship from Coordenação de Aperfeiçoamento de Pessoal de Nível Superior (CAPES) - Programa de Excelência Acadêmica (PROEX). The project was supported by grants from Fundação Carlos Chagas Filho de Amparo à Pesquisa do Estado do Rio de Janeiro (FAPERJ) and Conselho Nacional de Desenvolvimento Científico e Tecnológico (CNPq). We acknowledge two anonymous reviewers who contributed to improve this manuscript. We have complied with ethical standards in the treatment of our animals, adhering to national guidelines.

\section{RESUMO}

O objetivo deste estudo foi determinar a influência do aumento de temperatura associado à incidência luminosa na resposta funcional de Heleobia australis. Experimentos foram conduzidos utilizando nove a dez concentrações de alimento para cada tratamento: $20^{\circ} \mathrm{C} \mathrm{sem} \mathrm{luz,} 30^{\circ} \mathrm{C}$ sem luz e $30^{\circ} \mathrm{C}$ sob baixa incidência luminosa. Para cada experimento, a resposta funcional tipo III (sigmoidal) apresentou o melhor ajuste e os parâmetros das equações foram determinados. Os resultados sugerem que com o aumento da temperatura no sedimento, $H$. australis não terá sua taxa de ingestão afetada negativamente. Por outro lado, seu comportamento alimentar parece ser negativamente afetado pela incidência luminosa. As taxas de ingestão estimadas para o conteúdo orgânico na Baía de Guanabara foram: $0,34 \mu \mathrm{gC}$ ind $^{-1} \mathrm{~h}^{-1}$ a $20^{\circ} \mathrm{C}$ em ausência de luz, $1.44 \mu \mathrm{gC}$ ind $^{-1} \mathrm{~h}^{-1}$ a $30^{\circ} \mathrm{C}$ em ausência de luz e $0,64 \mu \mathrm{gC}$ ind $^{-1} \mathrm{~h}^{-1}$ a $30^{\circ} \mathrm{C}$ sob incidência luminosa. Nesta situação, as maiores taxas de ingestão foram estimadas em condições de alta temperatura, mesmo com incidência luminosa, sugerindo que a temperatura parece ter um efeito que predomina sobre o efeito da luz. Porém, considerando maiores concentrações de carbono, mesmo em temperatura alta, o experimento realizado com incidência luminosa apresentou taxas de ingestão mais baixas que aquelas do experimento conduzido a $20^{\circ} \mathrm{C}$ em ausência de luz. Este estudo fornece a primeira quantificação das taxas de ingestão de $H$. australis e os efeitos das modificações na temperatura e incidência luminosa no seu comportamento alimentar.

Palavras-chave: hidrobióide, taxas de ingestão, sistema estuarino, gastrópode.

\section{REFERENCES}

AbDel-Hamid ME, MonA MH AND Khalil AM. 1992. Effects of temperature, food and food concentrations on the growth of the larvae and spat of the edible oyster Crassostrea gigas (Thunberg). J Mar Biol Assoc India 34: 195-202.

Albertoni EF, Palma-Silva C AND Esteves FDA. 2003. Natural diet of three species of shrimp in a tropical coastal lagoon. Brazil Arch Biol Technol 46: 395-403. 
AldA P, BONEL N, CAZZANIGA NJ AND MARTORELLI SR. 2010 Effects of parasitism and environment on shell size of the South American intertidal mud snail Heleobia australis (Gastropoda). Estuar Coast Shelf Sci 87: 305-310.

Alvarez MF, Esquius KS, AdDINo M, ALBERTI J, IRIBARNe O AND BotTO F. 2013. Cascading top-down effects on estuarine intertidal meiofaunal and algal assemblages. J Exp Mar Biol Ecol 440: 216-224.

AMADOR ES. 1997. Baía de Guanabara e ecossistemas periféricos: Homem e natureza, Brasil, $1^{\text {st }}$ ed., Rio de Janeiro: Reporte Gráfica e Editora LTDA, 539 p.

APHA - American PUblic Health Association. 1998. Standard methods for examination of water and wastewater. Washington DC: US Government Printing Office, $1325 \mathrm{p}$.

BACH SS, Borum J, Fortes MD AND DUARTE CM. 1998. Species composition and plant performance of mixed seagrass beds along a siltation gradient at Cape Bolinao, The Philippines. Mar Ecol Prog Ser 174: 247-256.

BARNES RSK. 1986. Daily activity rhythms in the intertidal Gastropod Hydrobia ulvae (Pennant). Estuar Coast Shelf Sci 22: $325-334$

BARNES RSK. 2003. Feeding rates of continually submerged Hydrobia ulvae vary during the daylight hours. J Mar Biol UK 83: 1273-1275.

BARNES RSK. 2006. Variation in feeding rate of the intertidal mudsnail Hydrobia ulvae in relation to the tidal cycle. Mar Ecol Evol Persp 27: 154-159.

BEgON M, TOWNSEND CR AND HARPER JL. 2006. Ecology: from individuals to ecosystems, $4^{\text {th }}$ ed., Oxford: Blackwell Publishing Ltd, 738 p.

Bemvenuti CE, Cattaneo AS And Netto SA. 1992. Características estruturais da macrofauna bentônica em dois pontos da região estuarial da Lagoa dos Patos, RS, Brasil. Atlântica 14: 5-28.

BIANCHI T AND LEVINTON JS. 1984. The importance of microalgae, bacteria and particulate organic matter in the somatic growth of Hydrobia totteni. J Mar Res 42: 431-443.

Blanchard GF, GUARINI JM, PROVOT L, Richard P AND SAURIAU PG. 2000. Measurement of ingestion of Hydrobia ulvae (Pennant) on intertidal epipelic microalgae: the effect of mud snail density. J Exp Mar Biol Ecol 255: 247- 260.

Bougrier S, GeAiron P, DESLOUS-PAOLI JM, BATHER C AND JONQUIĖRES G. 1995. Allometric relationships and effects of temperature on clearance and oxygen consumption rates of Crassostrea gigas (Thunberg). Aquaculture 134: 143-154.

BUIKEMA AL. 1973. Some effects of light on the growth, molting, reproduction and survival of the cladoceran, Duphnia pulex. Hydrobiologia 41: 391-418.

CALOW P. 1975. The feeding strategies of two freshwater gastropods. Ancylus fluviatilis Mull and Planorbis contortus Linn (Pulmonata) in terms of ingestions rates and absorption efficiencies. Oecologia 20: 33-49.

Cuadrado DG, Gomez EA, Pierini JO AND Federici GA. 2006. A possible solution to Rosales Harbour excessive siltation rate (Bahia Blanca Estuary, Argentina). J Coast Res SI: 419-423.
De Francesco C AND Isla F. 2003. Distribution and abundance of hydrobiid snails in a mixed estuary and a coastal lagoon, Argentina. Estuar Coast 26: 790-797.

DE FranCESCO C AND IsLA F. 2004. The life cycle and growth of Heleobia australis (D'Orbigny, 1835) and H. conexa (Gaillard, 1974) (Gastropoda : Rissooidea) in Mar Chiquita coastal lagoon (Argentina). J Mollus Stud 70: 173-178.

ESPINOSA F, GUERRA-GARCÍA JM AND GARCÍA-GÓMEZ JC. 2007. Sewage pollution and extinction risk: an endangered limpet as a bioindicator? Biodivers Conserv 16: 377-397.

FIGUEIREDO-BARROS MP, LEAL JJF, ESTEVES FD, ROCHA AD AND BOZELLI RL. 2006. Life cycle, secondary production and nutrient stock in Heleobia australis (d'Orbigny 1835) (Gastropoda : Hydrobiidae) in a tropical coastal lagoon. Estuar Coast Shelf Sci 69: 87-95.

FIGUEIREDO GM AND VIEIRA JP. 1998. Cronologia alimentar e dieta da corvina, Micropogonias furnieri, no estuário da Lagoa dos Patos, RS, Brasil. Atlântica 20: 55-72.

Gitonga LM, Overholt WA, LOHR B, MAgAmbo JK AND MueKE JM. 2002. Functional response of Orius albidipennis (Hemiptera: Anthocoridae) to Megalurothrips sjostedt (Thysanoptera: Thripidae). Biol Control 24: 1-6.

GODOY JM, OLIVEIRA AV, ALMEIDA AC, GODOY MLDP, Moreira I, WAGENER AR AND JUNIOR AGF. 2012 Guanabara Bay sedimentation rates based on ${ }^{210} \mathrm{~Pb}$ dating: reviewing the existing data and adding new data. J Braz Chem Soc 23: 1265-1273.

GonÇALVES JR JF, FONSECA JJI AND CALlisto MFP. 1998 Population dynamics of Heleobia australis (Gastropoda) in a coastal lagoon (Rio de Janeiro, Brazil). Ver Int Ver Limnol 26: 2056-2057.

Grémare A, Duchêne JC, Rosenberg R, DAVID E AND DESMALADES M. 2004. Feeding behaviour and functional response of Abra ovata and A. nitida compared by image analysis. Mar Ecol Prog Ser 267: 195-208.

HAubois AG, GUARINI JM, RichaRd P, Fichet D, RADENAC $G$ AND BLANCHARD GF. 2005. Ingestion rate of the deposit-feeder Hydrobia ulvae (Gastropoda) on epipelic diatoms: effect of cell size and algal biomass. J Exp Mar Biol Ecol 317: 1-12.

Holling CS. 1959. Some characteristics of simple types of predation and parasitism. Canad Entomol 91: 385-398.

HolLING CS. 1965. The functional response of predators to prey density and its role in mimicry and population regulation. Mem Entomol Soc Can 45: 5-60.

Holling CS. 1966. The functional response of invertebrate predators to prey density. Mem Entomol Soc Can 48: 1-86.

HYLleberG J. 1975. The effect of salinity and temperature on egestion in mud snails (Gastropoda: Hydrobiidae). Oecologia 21: 279-289.

HYMEL SN AND PLANTE CJ. 2000. Feeding and bacteriolytic responses of the deposit-feeder Abarenicola pacifica (Polychaeta: Arenicolidae) to changes in temperature and sediment food concentration. Mar Biol 136: 1019-1027.

JICA. 1994. The study on recuperation of the Guanabara Bay ecosystem. Japan International Cooperation Agency. Kokusai Kogyo co, 8 volumes. 
Jorgensen P, BEMVENuti CE AND Hereu CM. 2009. Feeding of Farfantepenaeus paulensis (Pérez-Farfante, 1967) (Crustacea: Penaeidae) inside and outside experimental pen-culture in Southern Brazil. Panam J Aquat Sci 4: 39-51.

KAPUSTA SC AND BEMVENUTI CE. 1998. Atividade nictemeral de alimentação de juvenis de Callinectes sapidus, Rathbun, 1985 (Decapoda:Portunidae) numa pradaria de Ruppia maritima L.E estuarina da Lagoa dos Patos, RS, Brasil. Nauplius 6: 41-52.

KARRH RR AND MiLLER DC. 1994. Functional response of a surface-deposit feeder, Saccoglossus kowalevskii. Limnol Oceanogr 36: 1455-1464.

KenNedy VS, TWILley RR, KLEyPAS JA, COWAN JR JH AND HARE SR. 2002. Effects of global climate change on costal systems. In: Coastal and marine ecosystems and global climate change. Arlington: Pew Center on Global Climate Change, p. 7-25.

KIM TI, CHOI BH AND LeE SW. 2006. Hydrodynamics and sedimentation induced by large-scale coastal developments in the Keum River Estuary, Korea. Estuar Coast Shelf Sci 68: 515-528.

KofOED LH. 1975. The feeding biology of Hydrobia ventrosa (Montagu). I. The assimilation of different components of the food. J Exp Mar Biol Ecol 19: 233-241.

LINTON DL AND TAGHON GL. 2000. Feeding, growth, and fecundity of Abarenicola pacifica in relation to sediment organic concentration. J Exp Mar Biol Ecol 254: 85-107.

LiU YL, WANG YP, Li Y, GaO JH, Jia JJ, Xia XM AND GAO S. 2012. Coastal embayment long-term erosion/siltation associated with P-A relationships: a case study from Jiaozhou Bay, China. J Coast Res 28: 1236-1246.

NeVes RAF, ECHEVERria CA, PESSOA LA, PAIVA PC, PARANHos R AND VALENTIN JL. 2013. Factors influencing spatial patterns of molluscs in a eutrophic tropical bay. J Mar Biol Ass UK 93: 577-589.

NIXON SW. 1995. Coastal marine eutrophication: a definition, social causes, and future concerns. Ophelia 41: 199-219.

Oliveira A, PInTo TK, SANTOS DPD AND D'InCAO F. 2006. Dieta natural do siri azul Callinectes sapidus (Decapoda, Portunidae) na região estuarina da Lagoa dos Patos, Rio Grande, Rio Grande do Sul, Brasil. Iheringia Ser Zool 96: 305-313.

ORVAIN F AND SAURIAU PG. 2002. Environmental and behavioural factors affecting activity in the intertidal gastropod Hydrobia ulvae. J Exp Mar Biol Ecol 272: 191-216.

PASCAL PY, DUPUY C, RichaRd P, HAUBOUIS AG AND NiQUIL N. 2008. Influence of environment factors on bacterial ingestion rate of the deposit-feeder Hydrobia ulvae and comparison with meiofauna. J Sea Res 60: 151-156.

Pascal Py, Dupuy C, Richard P, MALlet C, Du Chatelet EA AND NiQUIL N. 2009. Seasonal variation in consumption of benthic bacteria by meio- and macrofauna in an intertidal mudflat. Limnol Oceanogr 54: 1048-1059.
PASCAL PY, FleEger JW, BoschKer HTS, MitWALly HM AND JOHNSON DS. 2013. Response of the benthic food web to short- and long-term nutrient enrichment in saltmarsh mudflats. Mar Ecol Prog Ser 474: 27-41.

Rabalais NN, TuRner RE, DíAz RJ AND JustiC D. 2009. Global change and eutrophication of coastal waters. J Mar Sci 66: 1528-1537.

RAO AMF AND CharetTe MA. 2012. Benthic Nitrogen Fixation in an Eutrophic Estuary Affected by Groundwater Discharge. J Coast Res 28: 477-485.

Rao VP, Shynu R, Kessarkar PM, Sundar D, Michael GS, NARVEKAR T, BLOSSON V AND MEHRA P. 2011. Suspended sediment dynamics on a seasonal scale in the Mandovi and Zuari estuaries, central west coast of India. Estuar Coast Shelf Sci 91: 78-86.

REAL L. 1977. The kinetics of functional response. American Naturalist 111: 289-300.

Rico-Villa B, POUVREAU S AND RoBert R. 2009. Influence of food density and temperature on ingestion, growth and settlement of Pacific oyster larvae, Crassostrea gigas. Aquaculture 287: 395-401.

RUSSEL FS. 1926. The vertical distribution of marine macroplankton IV. The apparent importance of light intensity as a controlling factor in the behaviour of certain species in the Plymouth Area. J Mar Biol Ass UK 14: 415-440.

SCHUMACHER BA. 2002. Methods for the determination of total organic carbon (TOC) in soils and sediments. Las Vegas: United States Environmental Protection Agency, 23 p.

Simon M AND AZAM F. 1989. Protein content and protein synthesis rates of planktonic marine bacteria. Mar Ecol Progr Ser 51: 201-213.

SMITH VH, TILMAN GD AND NEKOLA JC. 1999. Eutrophication: impacts of excess nutrient inputs on freshwater, marine, and terrestrial ecosystems. Environ Pollut 100: 179-196.

SOKOLOWSKI A, RICHARD P, FICHET D AND RADENAC G. 2005. Cd transfer in the deposit-feeder Prosobranch Hydrobia ulvae (Pennant) from benthic diatoms: the kinetics of rapid $\mathrm{Cd}$ assimilation and efflux. J Exp Mar Biol Ecol 317: 159-174.

VALENTIN JL, TENENBAUM DR, BONECKER ACT, BONECKER SLC, NogueIra CR AND VILlaC MC. 1999. O sistema planctônico da Baía de Guanabara: síntese do conhecimento. In: SILVA SHG AND LAVRADO HP (Eds), Ecologia de Ambientes Costeiros do Estado do Rio de Janeiro, Rio de Janeiro: PPGE-UFRJ, Rio de Janeiro, Brasil, p. 35-59.

Wolanski E, Moore K, Spagnol S, D'Adamo N and PATTIARATCHI C. 2001. Rapid, human-induced siltation of the macro-tidal Ord River Estuary, Western Australia. Estuar Coast Shelf Sci 53: 717-732. 
